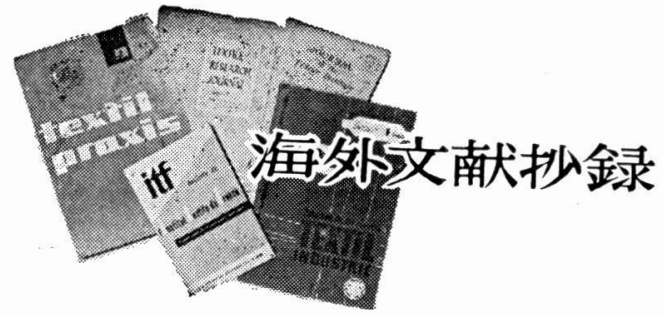

A. 㵶維ができるまで

羊毛と水の等温線に関する化学量論的解析; I.C.Watt ほか, J. Text. Inst., 353〜364 (1968-8)

$80 \%$ r.h. まで高めた湿度で羊毛のケラチン中の種々の タイプの側鎖の極性基に帰因する吸水量の決定によっ て, 羊毛と水の等温線の化学量論的解析が行なえる. 芳 香族（tyrosine）水酸性基と脂肪性（serine と threo nine）水酸基に吸収された量がこれらの基の化学的変態 を分離した後に水の吸収等温線の変化加ら決定された. 水分率の減少はアミノ基またはカルボキシル基の変態に ついての減少ほどではなかった。これらのデータは同一 条件のもとで試験した同種の水について以前に報告され ていた。

側鎖の塩基，カルボキシル基，水酸基に帰因する水の 量と変態化していない羊毛の水分率の差はペプチド基と アミド基につく水として示された，乙れらの基の水の吸 収力はポリグリシンのペプチド基についての実験データ とよい一致を示している，とのようにすべてのペプチド 基は水蒸気に近づきやすいようである. $75 \sim 80 \%$ r.h. で 羊毛一水の系の性質の変化は水素結合ネットワークの形 成に原因する，含んだ水はネットワーク水と呼ばれる.

(鈴木)

\section{B. 糸ができるまで}

アクリル絨維の紡績準備方法の比較；F. Daveloose,

Text. Chim., 465〜473 (1968-8)

大陸式前紡工程を用いた場合の結果を説明した前報に つついて, 今回は米式前紡工程 2 種を用いた場合のそれ ぞれについて第 3 および第 4 工程でできるスライバーや しのの性質およびその製造条件を説明し，とれらの前紡 工程上がりのしのを系にひいて䒺むらを比較している.

結論として, 大陸式が最もよく，米式第 1 種（ダブリ ング数 360）がこれにつき，米式第 2 種（ダブリング数 120）が最あ劣るといっている. むらについては米式第 1 種が最あ優秀であるが, 最終工程に粗紡機を用いるの でその保全が面倒であり，米式第 2 種では粗紡機を 2 工 程に用いているので，管理保全の手間が倍加する，乙れ に反して大陸式はむらの点では米式第 1 種よとやや劣る が, その差はそれほど大きくなく, しかも管理保全が容 易である。

（中島）

C. 布ができるまで

ポリエステル緎維のたて糸のりについて；H. Wolf, Melliand Textilber., 1080〜1081 (1968-9)
ポリエステル繊維はその化学組成によって疎水性でま た化学的に不活性であるので, いままでののり料はよく つかない。製織を高能率で行なうために他の繊維の場合 之同様ポリエステル繊維であのりつけが必要であるから よくついて摩擦に強いのりが開発されねばならない．ま た製織後のりは容易に除去されることが必要である。緎 維表面で固体化して機械的には分離しないが水によく溶 けるポリエステル用ののりがアクリルエステルをべース とした共重合レジンの粘稠な水溶液として市販されてい る. B A S Fののり T 8 タイプ $1211 \mathrm{C}$ で Trevira長㵶 維に使用されている。最近さらにのり $\mathrm{P}$ Eがてれに代わ って Du Pont の rotoset 糸に使用されている.のり量 は $45 \mathrm{~d} / 18 \mathrm{f}, 450 \mathrm{t} / \mathrm{m}$ 糸では $2 \% ， 60 \mathrm{~d}$ 無撚りには 4 〜 $5 \%$ Diolen Loft-PE 巻縮糸には $7 \%$ るるなど使用 法を説明し，とののり抜きにはアルカリ剂，湿潤剤を洗 浄浴に加え, 高温や浴交換で速くなる.酸では沈でんが できるなど洗浄の注意を示し，また綿との混紡系の場合 ののりつけには従来のでん粉のりは不十分で, ポリアク リルベースの高重合フィルム形成のり C と低粘度水溶性 でん粉誘導体または CMC誘導体とを $2 ： 19$ 割合とし たものに油とワックスとを添加したあのがよい. 68番手 系に固体 $13 \%$ 含有浴 $120 \%$ 付着して系重量 $15 \%$ 増加させ るなど混紡系ののりについても説明した。

（篠田）

\section{D. 染色仕上げ}

カーペット業界における最近の染色技術；W. Beal, J. Soc. Dyers Col., 3〜9 (1967-1)

カーペット業界における染色の最近の進歩を

1. バッチ式または単独の方法

2. 連続染色

の二つに大別して論じている.

内容は羊毛一ナイロンおよび羊毛一 $\operatorname{Evlan}($ レーヨン) 一ナイロン混紡品のバッチ染色の新しい技術と, これら を染めるときに使用する新しいタイプのナイロン防染剂 に関するものである. 無地, 濃淡染め, コントラストの 強い異色染めの可能なポリアミド緎維でできたカーペッ トのピース染色抢よび同様な効果の得られるオールウー ルのカーペットのピース染めについても論じている．ば ら毛, カードスライバー, トウおよびカーペットの形態 での種々の繊維の連続染色を論評し, 最後に合成繊維の スペース染色法についてす概説している. 〔海外繊維技 術文献集 2 月号に全訳掲載]

（藤野）

カーペットの連続仕上げ加工工程；Text. World, (1966-11)

カーペットの择染について, 特に連続捺染方式につい て述べたものである．細部についてはわかりにくいが, アメリカの実情がうかがえる.〔海外繊維技術文献集 2 月号に全訳掲載】

(尉斗)

異染性ポリアミドのタフテッドカーペットに關する染 色の問題点; Textilver., 856〜864 (1967-11)

均染型酸性染料に対して染料吸収量を異にする染料の タイプでの各 $\mathrm{pH}$ 領域における挙動を説明し，てれら瀻 維組み合わせカーペットの吸尽染色の状態, ジュート色 素污染防止の処置, 抗染繊維の挙動ならびに異染性力一 ペットの連続染色に関する状況などについて述へてい る.〔海外㵶維技術文献集 2 月号に全訳揭載〕

（藤野） 
タフテッド カーペットの大型ウインスによる染色の 機悈技術的経験；P. Ziegler, Textilver., 941(1967-11)

ブリックナー社のカーペット用特殊ウインスを中心と して, ウインスの自動化, 発展傾向などを説明. ての機 械は処理能力, 温度調節, 拡布装置に特色がある。連続 染色機と比較して経済的にあすぐれている，〔海外瀻維 技術文献集 2 月号に全訳掲載了

タフテッドカーペットの連続染色法; T.L.Dowson, Man-MadeText. and Skinn. Rec., 96 102(1967-10) タフテッドカーペットのピース染色は, ウインスを用 いたバッチ法で行なわれている。連続染色は労力, 蒸 気, 水の面から経済的であり, また生産性む高い。しか し他の分野と同様にどの工程で染色するかが問題であ り,カーペットの連続染色は, たとえば自動車用として レーヨン製品のみに限定されていた。最近では合成瀻維 ならびにその混紡系, 特にナイロン加工糸で作られたカ 一ペットの連続染色に関心が高まっている。〔海外瀻維 技術文献集 2 月号に全訳掲載了

ヨーロッパにおけるカーペットのプリント； H. R. Byland, Amer. Dyest. Rep., 101 106 (1967-12-12) ヨーロッパにおけるタフテッドカーペットのプリント は始まったばかりではあるが，見通しは明るい。一連の プリント装置, プリントペーストとして必要な各種薬剂 について説明し，カーペットに用いられる絨維に対する 染料, 用途について述へている. 〔海外織維技術文献集 2 月号に全訳揭載了

(長野)

ストークオイロマティック敷物加工装置; Textilver., 874〜875 (1967-11)

ストーク社のカーペット用万能ラチックス塗布機を紹 介している.〔海外繊維技術交献集 2 月号に全訳掲載〕

$$
\text { カーペットのバックコーティング; Melliand }
$$

Textilber., 450〜451 (1967-4)

各種のバックコーティング法を紹介している。〔海外 繊維技術文献集 2 月号に全訳掲載了

カーペットの連続ピース染色とその機械装置計画の示 唆; Melliand Textilber., 415〜420 (1957-4)

カーペットの染色仕上げ加工の方法は消費者の要求に 左右されるが, その際, 色彩とデザインが最も重要なも のとなろう。カーペット工業生産の増大とともにカーペ ットのいろいろな加工方式の中で後染めが最も重要な問 題となってきた。本文では最も合理的に経済的に操業す るために完全連続式で拡布染色する新しい方法とその可 能性について述べている。〔〔海外織維技術文献集 2 月号 《全訳掲載】

（篠田）

○カーペット業界に打ける最近の染色技術

○カーペットの連続加工工程

。異染性ポリアミドのタフテッドカーペットに関する 染色の問題点

○タフテッドカーペットの大型ウインスによる染色の

機械技術的経験

○カーペットの連続ピース染色とその機械装置計画の示
パッドスチーム法によるアクリル絨維のカーペットの 連続染色; U. Mayerほか, Melliand Textilber., (1967-4)

アクリルカーペットの連続染色は現在まず第 1 亿操作 技術が問題である。トップ，スライバーの連続染色の場 合，滞在時間はスチーマーの大きさにより $30 \sim 45 \mathrm{~min} ま$ で延長できる，し务しカーペットの場合，できるだけ短 いスチーミング時間に十分染料固着を行なわしめるとい うととが連続染色住対する本質的な前提条件である.

〔海外瀻維技術文献集 2 月号に全訳掲載〕

（熦田）

\section{I. 最終製品の製造と更生}

カーペットの商業試験, 引き渡し品質の評価とそのコ ントロール（第 2 報）；I. Cohen, J. Text. Inst., 181〜183 (1968-7)

カットパイルとループパイルについてタフトの移動お よびループのすべりに対する最小の抵抗という観点から 見たパイルの安全性について写真とともに示している. そして寸法の安全性については 2 inの細長い布に荷重を かけたときの伸びで示した。大量購入者のために品質管 理で目安となるあのをパイル系の構造, 1 in $^{2}$ 当たりの タフト数, $1 \mathrm{yd}^{2}$ 当たりのカーペットの重量, 動荷重で の厚さの損失，色の定着などの項目をあげている:

（鈴木）

カーペット工業におけるポリプロピレン紻維メラクロ ンの位置と意味; Textilver., 417〜423（1968-8）

瀻維床敷きに対しては, 新しい合成繊維と並んでポリ プロピレン繊維も推賞される。

カーペット市場の上での商業的技術的結果に対する評 判としてはつぎのような点が挙げられる.

すり切れ抵抗が大きい，污れを防ぐ性質がある，高度 の染色堅万う性がある, 被覆性が, 带電防止性がある, 難燃性がある, 強度が大きい, 温度安定性がある, 洗た くおよび乾燥清浄に対する安定性がある.

ミラノのポリマーSA 社のポリプロピレン繊維メラク ロンの性能は一般に上記の特性を考えるならば合理的に 判断されるようになった．㵶維の物理的特性は図示して 他の合成織維と比較してある.（藤野）

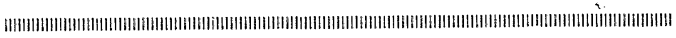

乙の欄には, 本会海外瀻維技術文献集編集委員会の編 集による「海外瀻維文献抄録」より，その一部を紹介す る。なお Dの項に紹介したすのは「海外絨維技術文献 集」2月号に「カーペットの染色加工特集号」としてー 括揭載されている。

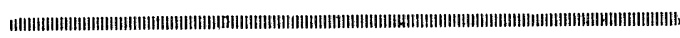

〈特集 >カーペットの染色加エ—

唆

○パッド スチーム法によるアクリル繊維のカーペット の連続染色

○タフテッドカーペットの連続染色法

。ヨーロッパに打けるカーペットのプリント

○カーペットのバックコーティング

。ストークオイロマチィック敷物加工装置 